\title{
DIKOTOMI MORAL DAN HUKUM SEBAGAI PROBLEM EPISTEMOLOGIS DALAM KONSTITUSI MODERN
}

\section{Syafruddin Muhtamar}

Program Doktor Ilmu Hukum Fakultas Hukum UNHAS

E-mail: syafruddinmuhtamar@gmail.com

\section{Muhammad Ashri}

Fakultas Hukum Universitas Hasanuddin

\section{Abstrak}

Fokus pembahasan dalam artikel ini adalah dikotomi moral dan hukum dalam konteks konstitusi modern yang mengakar pada pemikiran Thomas Aquinas dan Niccolo Machiavelli. Analisis difokuskan pada aspek epistemologis yang menjadi akar dikotomi panjang antara konsep moral dan hukum dalam konstitusi modern. Berdasarkan analisis yang telah dilakukan dapat disimpulkan bahwa paradigma hukum adi-kodrati dan positivisme merupakan akar epistemik dari dikotomi. Konstitusionalisme modern mendikotomikan konsep moral yang berorientasi pada kebenaran Ilahiah dan konsep hukum yang berorientasi pada kebenaran rasional. Dua konsep ini seharusnya direkatkan tanpa mendikotomikan yaitu melalui diktum 'pemuliaan moral dalam keutamaan hukum' sehingga dengan demikian hukum akan mampu menjawab problem peradaban.

Kata kunci: Moral, Hukum, dan Konstitusi Modern.

\section{Abstract}

This article discusses dichotomy between moral and legal consideration occuring in the modern constitutions that can be traced back in the thoughts of Thomas Aquinas and Niccolo Machiavelli. The analysis focuses on the epistemological aspects of this dichotomy that are rooted for long in the moral and legal concepts in the modern constitution. Through epistemological analysis, the authors conclude that the epistemic root of the dichotomy lie in the contrasting paradigm between supernatural law and modern positivism. While modern constitutionalism constructs moral concepts that presummes Divine truth, the legal concepts oriented to rational truth. These two concepts should be intergrated without dichotomy 
through the dictum 'moral exaltation in the primacy of the law' so that the law will be able to answer legal issues in the society.

Keywords: Moral, Law, and Modern Constitution.

\section{PENDAHULUAN}

Puncak dikotomi hukum dan moral meninggi ketika sistem kehidupan manusia memasuki abad modern. Wacana dikotomis ini tetap menjadi perbincangan ilmiah dan filosofis hingga detik ini. Harus disebutkan periode puncak pertentangan itu terjadi di abad modern ini karena satu alasan fundamental, yakni epistemologi pengetahuan modern. Artinya, sumber-sumber pengetahuan abad modern menjadi latar paling mungkin untuk disebutkan, karena dalam wilayah ini perdebatan terjadi, terutama filosof yang mempertahankan tradisi pemikiran klasik dan tradisi pemikiran yang lahir kemudian dalam paradigma baru oleh filosof modern. Paradigma baru ini, secara diametral menarik batas tajam bahkan cenderung menafikan kebenaran pengetahuan klasik, demi pengetahuan baru yang diperlukan bagi sejarah modern.

Hukum dan moral menjadi dua entitas sekaligus terminologi yang saling silang antara kenyataan dan pengertian di abad ini. Dimasa lampau, ketika epistemologi pengetahuan bertumpu pada kekuatan adikodrati dunia keilahiahan dan dewa-dewa, hukum dan moral saling mengidentifikasi. Hukum dipahami sebagai moral dan moral adalah hukum dalam konstruksi: hukum adalah wadah, moral adalah isi. Dalam pengertian tertentu, terjadi identifikasi nondikotomis; hukum adalah moral dan moral adalah hukum. Hal demikian ini tidak lagi dapat dengan mudah dikenali dalam sistem kehidupan modern. Ketika epistemologi pengetahuan bergeser dan berdiri di atas realitas logis kealaman dan empirik, atau secara ontologis bertumpu pada materialisme, maka realitas hukum dan moral menjadi menjadi terpisah dan bertolakbelakang.

Moral kemudian didudukkan sebagai produk dunia ideal ketuhanan, dan hukum diposisikan sebagai buah kehidupan sosial atau dunia rasional manusia. Karena hukum dianggap realistisrasional, dan moral idealis-irrasional, maka masyarakat modern 
hanya memberi ruang eksistensi lebih luas kepada hukum, dibandingkan peluang menghidupkan moral. Pada konteks inilah, dikotomi hukum dan moral dipahami sebagai problem epistemologis. Dikotomi tidak berhenti, karena pengaruh epistemologi berimplikasi pada fenomena sistem sosial dan hukum dalam skala hegemonik. Sisi lain, kesadaran akan kebenaran moral juga tidak sepenuhnya tereliminasi dari kehidupan masyarakat. Sementara, kebenaran hukum yang diterima dalam kesadaran mayoritas makin kokoh pengaruhnya dalam sistem kehidupan modern.

Fenomena ini menyisakan problem mendasar, terutama jika dikaitkan dengan term konstitusi atau konstitusionalisme, yaitu bagaimana kebenaran moral dapat menjadi dasar sistem hukum dan/atau konstitusi? Mengapa kebenaran moral dikesampingkan sebagai dasar konstitusi dan menyerahkan sepenuhnya kepada kebenaran hukum? Apakah ini disebabkan karena adanya asumsi keunggulan pada kebenaran rasional? Berdasarkan paparan tersebut maka fokus kajian pada artikel ini adalah analisis atas problem epistemologis dalam dikotomi hukum dan moral beserta implikasinya terhadap konstitusi modern.

\section{PEMBAHASAN}

\section{Problem Epistemologi Dikotomi Hukum dan Moral}

Dikotomi hukum dan moral berpangkal pada sejarah epistemologi pengetahuan manusia. Dapat dikatakan, dikotomi ini refleksi pertentangan atas dunia klasik (tradition) dan dunia baru (modern). Dua dunia ini memiliki dan dipengaruhi oleh model epistemologinya sendiri-sendiri. Fritjof Capra, ketika mengkomparasi sains abad pertengahan dan modern, menguraikan:

Sifat dasar ilmu pada Abad Pertengahan sangat berbeda dengan sifat dasar ilmu modern. Ilmu Abad Pertengahan didasarkan atas penalaran dan keimanan dan tujuan utamanya adalah memahami makna dan signifikansi segala sesuatu, dan bukan tujuan untuk peramalan dan pengendalian. Para ilmuwan pada Abad Pertengahan, yang mencari-cari tujuan dasar yang mendasari berbagai fenomena, menganggap 
pertanyaan-pertanyaan yang berhubungan dengan Tuhan, roh manusia, dan etika sebagai pertanyaan-pertanyaan yang memiliki signifikansi tinggi.

Pandangan Abad Pertengahan ini berubah secara mendasar pada abad ke enam belas dan tujuh belas. Pengertian alam semesta sebagai suatu yang bersifat organik, hidup, dan spiritual digantikan dengan pengertian bahwa dunia ini laksana sebuah mesin, dan mesin itu kemudian menjadi metafora yang dominan di zaman modern. Perkembangan ini diakibatkan oleh perubahan-perubahan revolusioner dalam ilmu fisika dan astronomi yang mencapai puncaknya pada prestasi yang dicapai oleh Copernicus, Galileo, dan Newton. Ilmu pada abad ke tujuh belas ini didasarkan atas suatu metode penelitian baru, yang dikembangkan dengan demikian kuat oleh Francis Bacon, dengan melibatkan deskripsi alam matematis dan metode penalaran analitik yang disusun oleh si jenius Descartes. Dengan peran ilmu yang sangat menentukan perubahanperubahan besar itu, para sejarawan sepakat menyebut abad ke enam belas dan tujuh belas sebagai Zaman Revolusi Ilmiah (Capra, 2000).

Uraian Capra tersebut mengindikasikan dua poros epistemologi yang 'bertentangan' tajam: satu menunjuk pada relasi harmoni antara keimanan dan rasio, sementara yang lain bersikukuh pada realitas alamiah dan rasio, dan menafikan keimanan. Yang disebut pertama, berorientasi pada Tuhan, roh manusia, dan moral serta etika, sementara yang disebut kedua berorientasi pada peramalan analitik terhadap gejala alam dan pengendalian. Dua epistemologi yang kontras secara fundamental ini kemudian memberikan pengaruh yang signifikan pada pengetahuan manusia. Pada tahap selanjutnya, epistemologi sains modernlah yang paling dominan pengaruhnya dalam berbagai bidang pengetahuan pasca dunia klasik (tradition).

Berdasarkan problem dasar dari epistemologi mengenai bagaimana pengetahuan itu diperoleh, dikenal beberapa metode memperoleh pengetahuan. Menurut Louis O. Kattsoff, metode- 
metode itu adalah, empirisisme, rasionalisme, fenomenalisme, intuisionisme, metode ilmiah (Kattsoff, 1996). Pendapat lainnya menyatakan: empirisme, rasionalisme, positivisme dan intuisionisme (Tafsir, 2011). Pendapat ini tidak memasukkan metode ilmiah sebagai aliran dalam epistemologi. Hal ini dapat diduga karena metode ilmiah secara substansial sudah terwakili dalam satu atau dua aliran tersebut. Sebagaimana lazim diketahui bahwa metode ilmiah yang digunakan oleh ilmu-ilmu alam menggabungkan pengalaman dan akal secara bersama sebagai pendekatan.

Berkaitan dengan terminologi hukum dan moral, maka jejak historis problem epistemologi ini dapat dilihat pada dua tokoh dan dua arus pemikiran utama, yang menjadi sumber pengetahuan tentang perdebatan dan pertentangan hukum dan moral, yakni Thomas Aquinas dan Niccolo Machiavelli, serta aliran pemikiran hukum alam dan aliran pemikiran positivisme. Thomas Aquinas adalah tokoh abad pertengahan yang merefleksikan epistemologi ketuhanan gerejawi dalam intelektualitas. Ajarannya tentang hukum terangkum dalam Summa Theologia, yang di dalamnya terdapat kerangka philosophia perennis. Aquinas mewakili epistemologi yang bersifat imania dan rasional, abad pertengahan. Sementara Niccolo Machiavelli, adalah pemikir politik yang menekankan rasionalitas kekuasaan tanpa justifikasi moral. Pemikiran Machiavelli tersebut sekaligus merefleksikan epistemologi abad renaissance (Schuon, 1998).

Dua tokoh tersebut membuat alur yang makin lama makin meneguhkan adanya perbedaan epistemologi dalam dua jalur, yakni imani-rasional dan alami-rasional. Sekaligus pada waktu bersamaan, memunculkan dua aliran filsafat, yaitu filsafat hukum alam dan filsafat positivisme. Kedua mahzab ini kemudian menjadi sumber utama dikotomi hukum dan moral, dalam sejarah panjang intelektualitas manusia. Carl Joachim Fredrich, menguraikan:

Setiap ahli hukum mengetahui rumusan hukum alam yang dilestarikan dalam Kitab Undang-undang Bizantium (Justinian Code). Disini hukum alam dibahas dalam tiga istilah, yakni jus natural, jus gentium, dan jus civile. Pembahasan ini dibuka dengan sebuah pernyataan dari Ulpian bahwa hukum alam adalah apa yang diajarkan oleh alam kepada semua mahluk 
hidup (animalia). Ada perbedaan antara konsepsi Romawi dan Yunani berkenaan dengan hukum, dimana perbedaan ini dapat dipahami dengan mengerti doktrin Stoik. Doktrin Stoik menyatakan bahwa umat manusia sebagai komunitas yang utuh. Satu Tuhan, satu hukum, satu negara. Manusia dibedakan dari sesamanya bukan karena ia menjadi anggota sebuah polis, melainkan karena ia seorang bijak. Mereka semua tunduk dalam satu Tuhan dan satu hukum (lex). Dalam Digest, Chrysipus Agung menjelaskan tentang nomos sebagai hukum dasar yang merupakan penguasa atas semua hal ilahiah dan manusiawi. Seperti ungkapan Ulpian, bahwa hukum bukanlah suatu yang khas spesies manusia, melainkan (ia merupakan hukum) atas semua mahluk hidup yang terlahir di langit, di bumi atau di laut (Friedrich, 2010).

Dari uraian ini, nampak jelas mengenai satu epistemologi tertentu, terutama doktrin kaum Stoik dan argumen Ulpian, dimana rasinonalisme hukum dan negara diharmonikan dengan keimanan. Kesadaran akan keilahiahan bercampur secara baik dengan dimensi rasional sebagai bagian dari alam (nature). Pandangan ini khas abad klasik dengan daya kuat secara kultural untuk menghasilkan pengetahuan yang diperoleh dari keterpaduan doktrin metafisik kepercayaan tertentu (adat istiadat atau agama) dengan kemampuan alamiah manusia dalam berpikir. Sementara disisi lain, filsafat positivisme, sebagai bagian perkembangan abad pencerahan (menuju abad modern) menekankan epistemologi yang juga khas. Progresivitas hadir sebagai epistemologi baru yang mengeliminir peran nilai metafisika atau doktrin religi/mistik dalam sejarah. Positivisme merupakan ujung tombak gerakan ini:

Positivisme adalah paham dalam filsafat ilmu pengetahuan yang berkembang sangat pervasif dan menurut Ian Hacking telah menjadi tidak hanya filsafat ilmu pengetahuan melainkan agama humanis modern. Positivisme menjadi agama karena telah melembagakan pandangan dunianya menjadi doktrin bagi berbagai bentuk pengetahuan manusia. Pandangan dunia yang dianut positivisme adalah pandangan dunia objektivistik. Pandangan dunia objektivistik 
menyatakan bahwa objek-objek fisik hadir independen dari subjek dan hadir secara langsung melalui data inderawi. Semesta dan data-data inderawi adalah satu. Apa yang dipersepsi adalah semesta sesungguhnya (Adian, 2002).

Positivisme melembagakan pandangan dunia objektivistiknya dalam suatu doktrin kesatuan pengetahuan. Doktrin ini mengatakan bahwa seluruh pengetahuan baik alam maupun manusia harus berada di bawah payung paradigma positivistik. Doktrin kesatuan ilmu mengajukan kriteria-kriteria bagi pengetahuan antara lain: bebas nilai, metode verifikasi-empiris, bahasa logis-empiris, dan eksplanatoris (Adian, 2002). Tokoh aliran ini adalah Auguste Comte (1798-1857). Ia berpendapat bahwa indera sangat penting dalam proses untuk memperoleh pengetahuan. Namun demikian, indra harus dipertajam dengan alat bantu dan diperkuat dengan eksperimen. Eksperimen memerlukan ukuran-ukuran yang jelas (Tafsir, 2004). Jadi pada dasarnya positivisme bukanlah aliran yang berdiri sendiri. Ia hanya menyempurnakan empirisisme dan rasionalisme yang bekerja sama.

Berikut bagan pengaruh epistemologi terhadap dikotomi hukum dan moral:

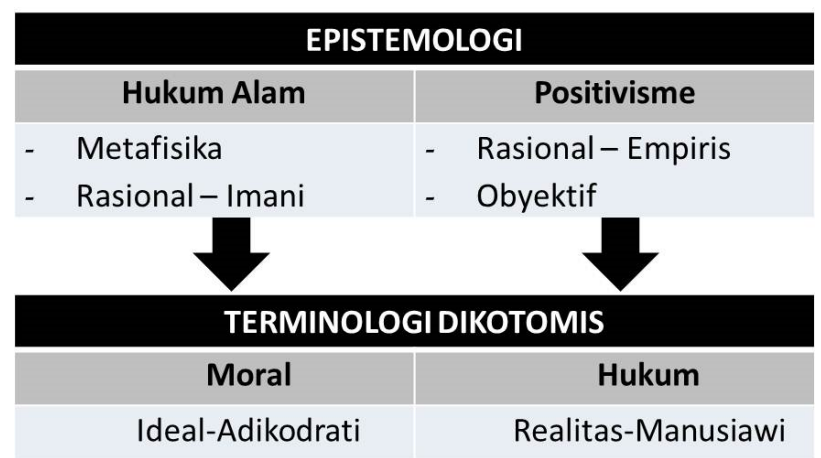

Bagan 1. Pengaruh epistemologi terhadap dikotomi hukum dan moral 
Gerakan ini membuat positivisme dominan di abad modern, bahkan dengan hegemoninya, menjadi pegangan suci para ilmuwan dan filosof. Pada awalnya positivisme adalah metode ilmu alam, namun karena kesuksesannya mewujudkan teknologi, maka pendekatan ini juga diterapkan dalam ilmu-ilmu kemasyarakatan. Positivisme adalah peruncingan trend sejarah pemikiran Barat modern yang menyingsing sejak ambruknya tatanan dunia Abad Pertengahan, melalui rasionalisme dan empirisme. Positivisme memiliki kekuatan pada metodologi ilmu pengetahuan, yang kemudian berkembang secara meyakinkan sejak Renaissance. Lebih tajam lagi Comte, menjelaskan istilah 'positif' itu dengan membuat beberapa distingsi:

'Yang nyata' (real) dan 'yang khayal' (chimerique), 'yang pasti' (certitude) dan 'yang meragukan' (indecesion), 'yang tepat' (precis) dan 'yang kabur' (vaque), 'yang berguna' (utilie) dan 'yang sia-sia' (oiseux), serta 'yang mengklaim memiliki kesahihan relatif' (relative) dan 'yang mengklaim memiliki kesahihan mutlak' (absolut) (Hardiman, 2016).

Pengaruh positivisme yang begitu kuat mampu menggeser metafisika sebagai produk pengetahuan Abad Pertengahan. Pergeseran ini didasarkan pada argumen bahwa kebenaran metafisika tidak dapat diverifikasi secara empiris. Popularitas positivisme ini pada akhirnya membuat sains atau ilmu pengetahuan ilmiah memisahkan diri dari metafisika dan filsafat untuk pertama kalinya. Dua epistemologi inilah yang menjadi akar problem dikotomi terminologi hukum dan moral, yang masih diwariskan oleh masyarakat intelektual hingga hari ini.

\section{Dimensi Ontologis Hukum, Moral, dan Konstitusi}

Terminologi hukum, moral dan konstitusi, adalah konsepkonsep kunci yang dapat digunakan untuk memahami idealitas dan realitas kehidupan, baik di zaman lampau maupun abad mutakhir. Beragamnya model epistemologi dan aliran filsafat, mendorong dan memungkinkan timbulnya ragam pengertian, pemahaman dan kesadaran tentang konsep-konsep tersebut. Pandangan mainstream 
seringkali dalam kesadaran tertentu dianggap pandangan yang benar, sehingga menyisihkan pandangan yang berbeda.

Berikut akan diuraikan secara ontologis, konsep hukum, moral dan konstitusi. Ini dimaksudkan sebagai deskripsi atas pengertian yang mengandung nilai ontologis, sehingga menuntun menguraikan problem; apakah kebenaran moral atau kebenaran hukum yang harus mewarnai suatu materi muatan konstitusi, atau konstitusionalisme modern dapat memberi ruang bagi terakomodasinya nilai-nilai moral dalam postulatnya sehingga ada titik pandang yang melepaskan sifat dikotomis antara hukum dan moral, dimana yang ideal dan yang realitas, yang ilahi dan yang manusiawi, atau yang profan dan yang sakral, melebur jadi satu kesadaran intelektual.

Dimensi ontologi dari konsep hukum, menurut Arief Sidharta, dapat dikaji dalam enam pendekatan aliran, yakni: ontologi hukum alam/kodrat, ontologi aliran positivisme hukum, ontologi aliran utilitarianisme, ontologi aliran mahzab sejarah, ontologi aliran sosiological jurisprudence, dan ontologi aliran realisme hukum (Atmadja, I. D. G \& Wiyono, 2014). Ragam pendekatan ontologis dalam ilmu hukum ini, dapat ditafsirkan melalui pengertian hakikat hukum itu sendiri. Demikian pula dengan konsep moral, yang dapat diklasifikasikan dalam dua arus utama, yakni moral religi atau spiritual, dan moral rasional atau ilmiah. Perbedaan ini juga tidak bebas dari model epistemologi dan ontologis. Abad modern adalah waktu bagi moral dan etika rasional-ilmiah, sementara abad sebelum modern, adalah masa kesuburan moral dan etika religius/spiritualitas. Jadi pendekatan ontologis yang digunakan berikut ini adalah yang melihat realitas sebagai suatu yang utuh dalam dirinya sendiri, sebagai kebenaran yang ilahi sekaligus manusiawi, yang imani sekaligus rasional, dan yang idealitas sekaligus realitas. Pendekatan ini mungkin condong ke ontologi hukum alam, khususnya yang meneguhkan argumen mistik/religi/keimanan dengan rasionalisme.

\section{a. Hakikat Hukum}

Menurut Aristoteles, hukum alam itu ialah hukum yang oleh orang-orang berpikiran sehat dirasakan sebagai selaras dengan 
kodrat alam. Thomas Aquinas (1225-1275) berpendapat, bahwa segala kejadian di alam dunia ini diperintah dan dikemudikan oleh suatu undang-undang abadi (lex eterna) yang menjadi dasar kekuasaan dari semua peraturan-peraturan lainnya. Lex Eterna ini adalah kehendak dan pikiran Tuhan yang menciptakan dunia ini. Manusia dikaruniai Tuhan dengan kemampuan berpikir dan kecakapan untuk membedakan baik dan buruk, serta mengenal berbagai peraturan perundang-undangan yang langsung berasal dari undang-undang abadi tersebut, yang oleh Thomas Aquinas dinamakan hukum alam (lex naturalis). Menurut Thomas Aquinas, hukum alam memuat azasazas umum seperti, berbuat baik dan menjauhi kejahatan, bertindak menurut pikiran sehat, dan mencintai diri sesama seperti kita mencintai diri sendiri. Azas ini mempunyai kekuatan mutlak, tidak mengenal kekecualian, berlaku dimana-mana dan tetap tidak berubah sepanjang zaman (Sudarsono, 1991).

Cicero salah seorang penganjur hukum alam, dalam uraian Carl Joachim Friedrich, menyebutkan:

Bahwa hukum alam mencakup ketundukan kepada Tuhan; kewajiban terhadap tanah air, orang tua dan saudara; hormat menghormati dan kesediaan untuk memaafkan; dan penghormatan kepada mereka yang lebih unggul dari kita dalam hal usia, kearifan, atau kedudukan, dan bahwa jus naturale juga mencakup kejujuran. Perilaku etis semacam ini menunjukkan kesetaraan manusia dengan fakta bahwa kegusaran, kesenangan, hasrat, dan kecemasan (molistiae, leatitiae, cupiditates, timores) adalah sama untuk semua manusia. Untuk memperkuat pendapatnya, Cicero bertanya: “Orang seperti apakah yang tidak menyukai kesantunan, kemurahan hati, dan sikap hormat, dan yang tidak membenci kesombongan, kekikiran, dan kekasaran?" Baginya semua ini seperti membuktikan kuatnya alasan untuk hidup dengan penuh keluhuran (ratio recte vivendi) yang merupakan kandungan kongkrit hukum alam yang mestinya mendasari semua tatanan hukum yang benar. Cicero sendiri bertindak sesuai dengan keyakinan itu ketika dia menjadi prokonsul (gubernur propinsi di era kekaisaran Romawi) di Cilicia, dia 
memerintah propinsi itu dengan kejujuran dan kelembutan, dan dia juga bertindak demikian ketika di Sicily (Friedrich, 2010).

Hakikat hukum dalam teori hukum alam ini, menunjukkan keutamaan nilai-nilai idealitas dari kemanusiaan sifat manusia, berkenaan keterikatannya terhadap yang Maha Tinggi, sehingga menyaratkan adanya kewajiban untuk tunduk. Adapun keterkaitannya dengan sesama makhluk manusia adalah untuk meninggikan nilai-nilai moril dan etis dalam segala manifestasinya dan memandang rendah sifat-sifat yang dapat mencoreng nilai-nilai pemanusiaan kehidupan manusia, yaitu kejahatan. Akal sehat ditempatkan sebagai bagian utama sebagai penghasil kebaikan dari apa yang merupakan dan memiliki keselarasan dengan kodrat alam. Artinya meskipun perspektif hukum alam berakar pada etika rasional sebagai sumber validitas universal, namun tetap membuka peluang yang luas bagi masuknya doktrin spiritualitas dan religi sebagai sesuatu yang secara rasional dapat diterima karena kesesuaiannya dengan kodrat alami kehidupan manusia.

Hakikat hukum haruslah berkenaan dengan kebenaran tertinggi dan implementasinya secara manusiawi dalam kerangka rasionalisme, yang meliputi lingkungan sosial dan alamnya. Artinya, hakikat hukum harus bertumpu pada tiga elemen dasar alam semesta, yakni Tuhan, manusia, dan alam (bumi). Kebenaran Tuhan harus menjadi sumber utama kebenaran hukum, dengan rasio manusia sebagai media perwujudannya hingga ke batas paling nyata pada hukum positif. Proses ini adalah rasionalisasi atas kebutuhan manusia akan kebenaran tertinggi dalam setiap kondisi dan keadaan sosial manusia dalam menjalankan kehidupannya. Dengan kata lain, aliran hukum alam masih memberi ruang bagi adanya kehendak tuhan sebagai dasar utama sebuah tatanan hukum.

Hans Kelsen, ketika mengurai mengenai hukum alam dan menyebutnya dengan nada kritik sebagai ideologi, karena pembenaran rasionalnya terhadap sebuah postulat didasarkan pada nilai subyektif, yakni pada kehendak, sebagai berikut:

Jenis ideologi semacam ini merupakan pernyataan bahwa suatu jenis tujuan akhir, dan dengan demikian suatu 
jenis peraturan tentang tingkah laku manusia, berasal dari "alam", yang lahir dari hakikat suatu benda atau hakikat manusia, dari penalaran manusia atau kehendak Tuhan. Dalam asumsi semacam ini terkandung esensi yang disebut hukum alam. Doktrin ini beranggapan bahwa ada suatu keteraturan hubungan-hubungan manusia yang berbeda dengan hukum positif, yang lebih tinggi dan sepenuhnya sahih dan adil, karena berasal dari alam, dari penalaran manusia dan dari kehendak Tuhan.

Kehendak Tuhan menurut doktrin hukum alam sama dengan alam bila alam dipahami sebagai ciptaan Tuhan, dan hukum alam sebagai ungkapan dari kehendak Tuhan. Oleh sebab itu, menurut doktrin ini, hukum yang menentukan alam mempunyai karakter yang sama dengan peraturan hukum yang dikeluarkan oleh pembuat undang-undang. Hukum tersebut merupakan perintah yang ditujukan kepada alam; dan alam mematuhi perintah ini, yakni hukum alam ini, persis sebagaimana manusia mematuhi hukum yang dibuat oleh pembuat undang-undang. Hukum alam, sesuai dengan doktrinnya yang khas, tidak diciptakan oleh tindakan kehendak manusia; hukum alam bukan merupakan produk manusia yang bersifat tiruan atau sembarang. Hukum alam dapat dan harus direduksi dari alam melalui suatu tatanan kerja mental. Hak dan kewajiban manusia yang ditentukan oleh hukum alam ini dianggap telah dibawa sejak lahir atau ada dalam diri manusia karena ditahbiskan oleh alam dan tidak dibebankan kepadanya oleh pembuat undang-undang dari kalangan manusia; dan selama alam mengejawantahkan kehendak Tuhan, maka hak dan kewajiban ini suci (Kelsen, 2015).

Pada jalur refleksi pemikiran lain, ditemukan hakikat hukum yang kontras dengan apa yang direduksikan dari hukum alam. Jalur itu adalah positivisme hukum. Dalam definisi tradisional tentang hakikat hukum, positivisme memaknai hukum sebagai norma-norma positif dalam sistem perundang-undangan. D. Darmodhihardjo dan Sidharta, menjelaskan bahwa positivisme hukum memandang perlu 
pemisahan secara tegas antara hukum dan moral. Hukum dan moral dianggap memiliki otonomi yang eksklusif masing-masing, dan tidak berhubungan satu sama lain (Susanto, 2010).

Positivisme hukum memandang pemisahan hukum dan moral adalah hal yang teramat penting. Positivisme membedakan secara tajam antara: "what it is for a norm to exist as a valid law standart" dengan "what it is for a norm to exist as a valid moral standart" (Patterson, 1999). Jadi positivisme hukum secara tegas membedakan apa yang membuat suatu norma menjadi eksis sebagai suatu standar hukum yang valid dan apa yang membuat suatu norma menjadi eksis sebagai suatu standar moral yang valid. Bagi kaum positivis, norma-norma yang tergolong bengis pun, dapat diterima sebagai hukum, asalkan memenuhi kriteria formal yang ada tentang hukum.

Jhon Austin menyebutkan, "Law is a command set, either directly or circuitously, by sovereign individual or body, to a member or members of some independent political society in which his authority is supreme". Jadi, hukum adalah seperangkat perintah, baik langsung maupun tidak langsung, dari pihak penguasa kepada warga masyarakatnya yang merupakan masyarakat politik yang independen, dimana otoritasnya (pihak yang berkuasa) merupakan otoritas tertinggi. Austin mendefinisikan hukum sebagai perintah dari yang berdaulat dalam masyarakat (Ali, 2009).

Hakikat hukum dalam pandangan positivisme bersemangat kuat untuk melepaskan hukum dari dimensi non-hukum. Hakikat hukum tiada lain adalah perintah dari pemegang kekuasaan negara atau otoritas politik dalam masyarakat. Keadilan bukanlah esensi dari hukum, karena yang esensial adalah perintah penguasa yang mengandung kewajiban. Sebagaimana Hans Kelsen menyebutnya sebagai suatu perintah memaksa terhadap perilaku manusia. Hukum adalah kaidah primer yang menetapkan sanksi-sanksi. Karena itu esensi hukum positif adalah perintah dan sanksi dari yang berdaulat, demi timbulnya kemanfaatan atau ketertiban tertentu yang diasumsikan rasional menurut pengalaman sosial. Moral atau keadilan tidak menjadi esensi dari hukum positif karena dimensi idealitasnya. Hukum positif berlandaskan realitas yang kemudian 
diabstraksikan menjadi norma tertentu dalam suatu kerangka yuridis dan harus melalui mekanisme politik negara.

\section{b. Hakikat Moral}

Hakikat moral dapat diurai dengan terlebih dahulu memahami maknanya dari sisi etimologis. Kata moral berasal dari bahasa latin mos (jamak: mores) artinya kebiasaan atau adat. Dalam bahasa Inggris, kata mores masih dipakai dalam arti yang sama yaitu kebiasaan. Moral juga mempunyai arti yang sama dengan moralitas yang dalam bahasa latin disebut dengan moralis (Kusuma, 2015). Dalam Kamus besar Bahasa Indonesia moral diartikan sebagai (1) ajaran baik atau buruk yang diterima umum mengenai perbuatan, sikap, kewajiban, dan sebagainya, (2) kondisi mental yang membuat orang tetap berani, bersemangat, bergairah, berdisiplin, dan sebagainya atau dengan kata lain isi hati/keadaan perasaan sebagaimana terungkap diperbuatan, (3) ajaran kesusilaan yang dapat ditarik dari suatu cerita. Maka dari segi etimologi, moral menunjuk pada suatu kebiasaan atau adat, atau perbuatan dan sikap yang mengandung kebaikan atau kesusilaan.

Bertens mengatakan bahwa moral merupakan nilai-nilai dan norma-norma yang menjadi pedoman bagi seseorang maupun kelompok yang digunakan untuk mengatur suatu perbuatan (Bertens, 2007). Sementara, Ensiklopedi Nasional Indonesia menjelaskan bahwa moral merupakan salah satu cabang ilmu filsafat yang secara khusus mempelajari dan berbicara tentang tingkah laku manusia. Moral dikatakan sebagai norma maka akan berbicara mengenai bagaimana orang harus bertindak. Sehingga dapat dikatakan bahwa moral merupakan suatu ciri berperilaku seseorang yang dihubungkan dengan ukuran yang ada dalam masyarakat, khususnya mengenai perilaku baik atau buruk, moralitas bukan sesuatu yang diperoleh dari kelahiran melainkan tumbuh dan berkembang dalam lingkungan hidup (Tim Penulis Cipta Adi Pusaka, 1990) Franz Magnis Suseno ketika mengemukakan perbedaan moral dan etika, menyatakan bahwa moral adalah ajaranajaran, ketentuan-ketentuan, petunjuk-petunjuk, dan ketetapanketetapan tentang bagaimana manusia harus hidup menjadi manusia 
yang baik. Dengan demikian, apabila ajaran-ajaran moral mengandung perintah untuk mengikuti dan melaksanakan ajaranajaran tertentu, maka etika hendak memahami mengapa manusia mesti mengikuti ajaran-ajaran yang diperintahkan untuk diikuti itu. Karena itu, etika dapat dipandang mengandung kekurangan karena tidak berwenang memerintah. Namun sekaligus mengandung kelebihan karena etika menjadikan manusia memahami mengapa ia mesti mengikuti perintah ajaran-ajaran tertentu (Suseno, 2006).

Beragam definisi ini menunjukkan bahwa terminologi moral secara esensial dapat dipahami sebagai akumulasi dari tiga elemen utama manusia, yakni nilai, sikap dan perilaku. Elemen ini terikat pada pandangan dunia atau kebenaran tertentu yang hidup dalam masyarakat dan secara terus-menerus memengaruhi kehidupan masyarakat secara kontinyu. Dari segi aspek nilai, moral dekat dengan ajaran atau doktrin religius, meskipun ada juga nilai moral yang berbasis pada kearifan kultur tertentu (adat). Namun jika dilacak, nilai-nilai moral-adat itu, juga dipengaruhi ajaran keagamaan tertentu yang secara general menempatkan kebenaran transendental sebagai awal dan sumber kebaikan moral. Bahkan jika moralitas adat itu bersifat murni, tetap dimensi sakralitas dunia adikodrati menempati posisi fundamental dalam sistem adat tersebut. Ini menunjukkan hakikat moral secara esensial berkaitan dengan ajaranajaran kesucian, kemuliaan, dan kebaikan kehidupan dunia sekarang dan dunia yang akan datang.

Salah satunya dapat diketahui dari pandangan al-Ghazali tentang moral, dalam uraian George F. Hourani, berikut ini:

Pandangan moral al-Ghazali lebih bersifat praktis-keagamaan, yaitu diarahkan pada pencapaian kebahagiaan ukhrawi. Dalam pandangan moralnya, al-Ghazali menempatkan akal sebagai pengendali nafsu dan efisiensi dalam mencapai tujuan praktis seseorang, sehingga yang terpenting adalah bagaimana akal dapat mengarahkan kepada tindakan perbuatan yang benar secara moral keagamaan dalam rangka mencapai kebahagiaan ukhrawi. Pandangan moral semacam inilah yang disebut oleh George F. Hourani sebagai ethical voluntarist, yaitu pandangan-pandangan moral yang hanya mengacu kepada 
aspek diperintahkan atau tidak diperintahkan oleh agama sebagai standar penilaian (Hourani, 1980). Menurut al-Ghazali, kebahagiaan ukhrawi yang menjadi tujuan moral tersebut mempunyai ciri-ciri yang khas, yaitu berkelanjutan tanpa akhir, kegembiraan tanpa duka-cita, pengetahuan tanpa kebodohan, dan kecukupan (ghina) yang tak membutuhkan apa-apa lagi guna kepuasan yang sempurna (surga) (Quasem, 1988).

Jadi, esensi moral adalah pedoman kemanusiaan menjalankan kehidupan diatas landasan nilai kebaikan. Moral berkenaan dengan rasionalitas dunia keimanan dan keilahiyahan karena menyangkut kebahagiaan manusia sebagai mahluk bumi dan mahluk ukhrawi. Moral sebagai pedoman kehidupan, mengandung pengertian bahwa pedoman ini berkaitan dengan hakikat manusia sendiri, sebagai makhluk jasmani dan rohani. Nilai-nilai kebaikan moral haruslah selaras dengan manusia sebagai makhluk multi dimensi, terutama sebagai makhluk ciptaan Tuhan yang dalam dirinya terkandung citra ketuhanan. Citra ketuhanan ini yang mengikat manusia secara fitrah untuk wajib memiliki jalan kebahagiaan, tidak hanya secara material (dunia) tetapi juga spiritual.

\section{c. Hakikat Konstitusi}

Konstitusi sebagai istilah memiliki ragam pengertian. Para ahli dalam memberikan pengertian membagi dua kategori pengertian yang digunakan, yakni pengertian dalam arti luas dan sempit. Sudut pandang ahli memberi pendefinisian pada istilah itu juga beragam. Tetapi umumnya menggunakan sudut pandang hukum dan politik sehingga teori tentang konstitusi menjadi dinamis.

Djokosutono dalam materi-materi kuliahnya yang dihimpun Harun Al-Rasid, mengatakan:

Bahwa jika menggunakan paham Lasselle sesuai ilmu politik, Pertama, konstitusi dapat didefinisikan sebagai hubungan antar kekuasaan-kekuasaan yang terdapat dengan nyata dalam suatu negara. Kedua, konstitusi dapat juga didefinisikan sebagai naskah, diatas kertas, dimana semua bangunan-bangunan negara dan sendi-sendi pemerintahan 
diletakkan. Paham Lasselle yang cocok dengan paham modern adalah mengenai 'bentuk' konstitusi yaitu harus merupakan naskah tertulis (Djokosutono, 1982). Teori bentuk konstitusi menurut Lassalle ini bersesuaian dengan perubahan dalam zaman modern dimana mayoritas bentuk konstitusi negara modern adalah tertulis. Sementara itu James Bryce mendefinisikan konstitusi, sebagai: "Suatu kerangka masyarakat politik (negara) yang diorganisir dengan dan melalui hukum. Dengan kata lain, hukum menetapkan adanya lembaga-lembaga permanen dengan fungsi yang telah diakui dan hak-hak yang telah ditetapkan".

Lebih jauh C.F Strong menambahkan bahwa konstitusi dapat pula dikatakan sebagai kumpulan prinsip-prinsip yang mengatur kekuasaan pemerintahan, hak-hak pihak yang diperintah (rakyat) dan hubungan antar keduanya. Konstitusi dapat berupa sebuah catatan tertulis; konstitusi dapat ditemukan dalam bentuk dokumen yang bisa diubah atau diamandemen menurut kebutuhan dan perkembangan zaman; atau konstitusi dapat juga berwujud sekumpulan hukum terpisah dan memiliki otoritas khusus sebagai hukum konstitusi. Atau, dapat juga dasar-dasar konstitusi tersebut ditetapkan dalam satu atau dua Undang-undang Dasar sedangkan selebihnya bergantung pada otoritas kekuatan adat istiadat atau kebiasaan (Strong, 2010).

Argumen James Bryce dan C.F Strong mengenai teori konstitusi tersebut mewakili dua perspektif, politik dan hukum sekaligus. Kedua pengertian tersebut sifatnya komprehensif dan melingkupi beragam dimensi dalam kedua bidang ilmu tersebut. Terutama dalam pandangan Strong yang melihat konstitusi sebagai dokumen tertulis (modern) tetapi juga secara tradisional dalam dimensi adat istiadat atau kebiasaan.

Dalam analisa lebih teknis, konstitusi sebagai konsep dilihat dari dua level yang berbeda, yang pertama disebut sebagai kontitusi positif (as it is) dan yang kedua konstitusi normatif (as it ougt to be). Yang disebut konstitusi positif adalah konstitusi yang diformulasikan oleh sebuah kekuasaan yang sah, apakah basisnya berupa 
penerimaan atau pengakuan rakyat maupun yang basisnya adalah kewenangan atributif. Sementara konstitusi normatif adalah konstitusi yang dicita-citakan, konstitusi dengan nilai-nilai ideal (Kurnia, 2014).

Membedakan konstitusi positif dan normatif ini penting bagi Cristoph Mollers karena, perkonsepsi konstitusi dianggap kabur dari segi makna sebab didekati banyak perspektif. Agar jelas makna konstitusi itu, Mollers menawarkan 3 (tiga) level analisis untuk mengetahui makna konstitusi: "a theoretical level that reflects the term with regard to history and legitimacy; a normative level that applies the term as an element of the legal system; and a descriptive level that use contitutions as a term to analyse institutions" (Kurnia, 2014).

Bersandar pada pendapat Mollers, maka dipahami bahwa konstitusi pada satu level (teoritis) adalah istilah yang merefleksikan sejarah dan legitimasi/kekuasaan, dalam hal ini konstitusi dapat dipandang sebagai teori yang berkenaan dengan sejarah peristilahan konstitusi yang kandungan pengertiannya berbeda-beda berdasarkan konteks zaman terutama mengenai legitimasi kekuasaan-kekuasaan negara dalam sejarah tersebut. Sementara pada level yang lain (normatif), konstitusi dimaknai sebagai bagian dari suatu sistem hukum. Pada konteks ini konstitusi dipandang lebih fungsional sebagai bagian dari sebuah sistem hukum. Apabila merujuk pada teori-teori konstitusi sebelumnya, maka konstitusi dilevel ini merupakan kaidah-kaidah dan/atau norma-norma hukum yang menjadi dasar dari suatu sistem hukum.

\section{Kesetimbangan Moral dan Hukum}

Diperlukan diktum untuk menghindar dari jurang terjal moral dan hukum dalam pengetahuan modern. Hegemoni kesadaran mengenai kebenaran hukum modern, telah menimbulkan kecurigaan tiada henti pada kebenaran moral. Oleh karena itu, sebuah diktum diperlukan untuk mendamaikan dua pandangan dikotomis ini, antara kebenaran moral dan kebenaran hukum. Diktum ini akan melepaskan polemik epistemologis dan ontologi dalam dua konsep dasar hukum, moral, dan konstitusi. Hal ini disebabkan karena jika 
dibiarkan tanpa titik sambung, maka kontinuitas hegemonik kebenaran profan atas kebenaran sakral akan makin kokoh.

Diktum itu dapat berbunyi: "Memuliakan Moral dalam Keutamaan Hukum". Determinasi diktum ini untuk menghilangkan corak dikotomis kebenaran moral dan hukum, melepaskan konsep besar itu dari pengaruh historikal basis argumennya, dengan meletakkan diatas dasar realitas kebenaran tidak terpisah, tetapi keduanya terhubung secara timbal balik. Artinya moralitas harus dianggap sendi utama eksistensi hukum, yang tanpanya kebenaran hukum tidak dapat dibenarkan. Berdasarkan hal ini maka tidak ada dualisme hukum dan moral. Moral pada konteks argumen ini dipandang sebagai materi yang bentuk-nya dapat dilihat dalam hukum. Jadi hukum semata-mata haruslah merupakan kelanjutan dunia material moral dalam dunia bentuk hukum. Dengan demikian dua konsep ini saling mengidentifikasi, moral menjadi sama dengan hukum dan hukum menjadi sama dengan moral. Berikut bagan yang menggambarkan identifikasi kebenaran moral dan hukum:

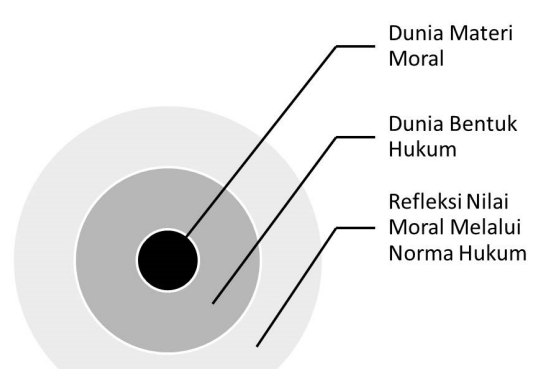

Bagan 2. Identifikasi kebenaran hukum dan moral

Argumentasi tersebut di atas dibangun berdasarkan pada dua realitas : (1) dunia hukum modern menarik jarak lebar dari moral (dunia sakral) dan (2) ketidaksanggupan dunia hukum menghindar dari kebenaran moral, khususnya moral rasional/kebenaran ilmiah (dijustifikasi sebagai nilai moral). Dari fakta ini, maka dunia hukum modern hanya menolak moral bercorak religius dengan sakralitasnya. Moral religi dianggap tidak memiliki pijakan rasio, karena menyangkut realitas mistik/ keyakinan. 
Berkenaan dengan hal tersebut, maka menarik melihat gagasan moral Imanuel Kant. Kant memperlihatkan bahwa rasio membentuk argumentasi-argumentasi dengan dipimpin oleh tiga ide, yaitu jiwa, dunia dan Allah. Dengan ide inilah Kant ingin mencapai kesatuan terakhir dalam bidang jiwa, dunia dan Allah. Ketiga ide itu mengatur pengenalan kita, tapi tidak termasuk pengalaman. Karena kategori hanya sampai pada apa yang dapat dialami (Tafsir, 2011). Kant mengatakan bahwa moralitas adalah hal yang menyangkut baik dan buruk, tetapi bukan sembarang yang baik dan buruk, melainkan, dalam bahasa Kant, apa yang baik pada dirinya sendiri tanpa pembatasan. Sedang kebaikan yang tanpa pembatasan adalah kehendak baik. Berbeda dengan hal itu, adalah bakat rohani, ciri perangai dan sifat-sifat watak seseorang hanya akan mempunyai nilai moral apabila diabdikan pada kehendak baik itu, kehendak yang menentukan apakah watak orang dipakai dengan baik atau buruk. Syarat kebaikan berbagai sifat manusia adalah kehendaknya yang baik (Suseno, 1997).

Argumen Kant ini, dapat menjadi acuan pemikiran masyarakat modern yang memandang kebenaran hukum dan kebenaran moral secara terpisah. Gagasan ini menguatkan realitas sejati dari kehidupan manusia, yakni tidak terpisahnya antara dunia ideal dengan realitas, antara rohani dengan materi, antara seharusnya dengan senyatanya, antara sakral dan profan, antara imani dan rasional, dan antara ukrawi dan duniawi. Dasar postulasi Kant dapat menjembatani dikotomi hukum dan moral. Artinya keterpisahan kebenaran hukum dan moral, terjadi karena dasar postulasi yang digunakan memandang kedua konsep tersebut sudah memisahkan sejak awal, karena epistemologi, yang memandang adanya keterpisahan dunia materi dan roh, atau dualisme.

Dengan demikian, pandangan dunia modern dapat bertumpu pada kemenyatuan rohani dan materi, untuk terhindar dari kesalahan fatal sindrom dikotomi ini. Realitas modern tiada henti terpola dalam baik dan buruk menurut moral rohani/imani atau menurut moral materi/rasio-empiris/positivisme. Kemudian menempati wilayah masing-masing. Moral imani pada wilayah individual atau subyektivisme, moral positivis pada wilayah sosial 
atau obyektivisme. Implikasinya adalah kepribadian sosialkemasyarakatan terbelah. Eksistensi manusia bergelut dalam satu ruang hidup dengan dua kapling kebenaran, yakni kebenaran individual dan kebenaran sosial.

Sederhananya, manusia hidup dalam kemenduaan sumber nilai, yakni yang bersumber dari pandangan dunia tradisi (agama dan spiritualitas) dan bersumber pada pandangan dunia modern (rasionalitas ilmiah). Ini dapat dilihat dari gambaran H.L.A. Hart, ketika menulis hubungan antara moral dan hukum, berikut ini:

Dari berbagai literatur sejak dari Plato sampai ke masa sekarang, yang dicurahkan untuk mendukung dan membantah, proposisi bahwa cara-cara seharusnya manusia berperilaku bisa ditemukan oleh pikiran, mereka bersengketa disalah satu pihak nampaknya berkata, "Anda buta jika tidak bisa melihat hal ini", namun menerima jawaban, "Anda yang sedang bermimpi". Hal seperti ini terjadi karena klaim adanya prinsip faktual mengenai perilaku yang benar, yang dapat ditemukan secara rasional, biasanya tidak ditemukan sebagai doktrin tersendiri melainkan sejak awal disajikan, dan dipertahankan dalam waktu lama, sebagai sebuah konsepsi umum mengenai alam semesta, meliputi benda hidup dan mati. Pandangan ini, dalam banyak hal, merupakan antitesis atas konsepsi umum alam semesta yang membentuk kerangka pemikiran sekuler. Dari sini, teori Hukum Alam terlihat muncul dari kekacauan lama yang darinya pemikiran modern telah membebaskan diri secara gemilang (Hart, 2013).

Menurut Finnis, teori-teori hukum kodrat klasik dan penalaran praktis memberikan landasan rasional bagi penilaian moral. Hukum kodrat adalah sesuatu yang disediakan bagi manusia agar dapat bertindak dengan adil dalam berhubungan dengan satu sama lain (Ward, 2014). Hal ini merupakan kritik terhadap kenyataan sejarah yang menunjukkan kebangkitan negara sekuler dari waktu ke waktu yang membuat teori-teori hukum teologis menjadi semakin termarjinalkan sementara resolusi konstitusi Hooker terus menikmati relevansi kontemporer tertentu, dimana pemikiran tentang 
persemakmuran suci hampir lenyap dalam wacana politis modern (Hart, 2013).

\section{Relasi Kebenaran Moral dan Hukum dalam Konstitusi Modern}

Konstitusionalisme modern mengalami 'dilema' dalam membangun pondasi nilai konstitusi, dalam konteks kaitan moral dan hukum, karena konstitusi adalah derivasi term hukum secara langsung. Meskipun konstitusionalisme menggambarkan nilai normatifnya sendiri, dalam HAM (hak asasi manusia), pembatasan kekuasaan, dan struktur kekuasaan negara. Materi muatan konstitusi modern secara epistemologis bercorak rasional-empiris atau positivism dan secara ontologis mengedepankan watak materialisme ketimbang spiritualisme. Secara keseluruhan sistem hukum modern berkarakter sekular, demikian pula konstitusionalitasnya.

Dengan model konstitusionalisme seperti itu, maka ada banyak problem yang tersisakan. Secara kasuistik menimbulkan goncangan terhadap konstitusi modern. Misalnya, fakta masif tentang bakat alami (asumsi) untuk menjalin hubungan sesama jenis pada seluruh bangsa dimuka bumi. Jika dasar hubungan ini dianggap alamiah, maka disebut perbuatan itu manusiawi dan normal sebagaimana hubungan berlainan jenis. Fakta ini dianggap sebagai gejala sosial dengan kebenarannya sendiri dan diberi label sebagai satu masyarakat tertentu. Karena berstatus masyarakat, maka terdapat konsekuensi hukum dan konstitusionalitas dalam hak dan kewajiban. Keberadaan masyarakat baru ini dengan ciri hubungan sesama jenis akhirnya meminta adanya perlindungan hukum dalam konstitusi sebagai masyarakat yang berkebutuhan khusus dalam seksualitas.

Jika dipaksakan dalam logika konstitusionalisme modern, dengan dasar HAM, maka peluang mereka untuk diakomodir dalam perlindungan hukum konstitusi terbuka lebar. Pada beberapa konstitusi negara modern Barat, masyarakat baru ini mendapatkan hak-haknya sebagaimana warga negara lain dalam hal perkawinan dan berketurunan. Namun di negara-negara Timur dengan kesadaran moral religi/spiritualitas yang masih bertempat di hati masyarakat, problem masyarakat baru ini menjadi polemik panjang 
dan sengit. Menurut pandangan peneliti, fenomena LGBT (lesbian, gay, biseksual dan transgender) bukan sebagai problem hukum atau konstitusi, tetapi lebih merupakan problem moral sehingga bakat menyukai sesama jenis ini bukanlah dasar lahirnya hak sosial tertentu. Hal ini merupakan penyimpangan moral sejak awal, sehingga menjadi kewajiban moral bagi institusi keluarga, sekolah maupun negara, untuk meluruskan penyimpangan tersebut.

Hal tersebut di atas hanyalah salah satu contoh dimana konstitusionalisme modern memerlukan reorientasi kebenaran, mengenai apa nilai dasar dan fundamental bagi konstitusi. Kebenaran harus dikembalikan ke sendi dasarnya dalam moral religi/spiritual. Dengan sendi moral yang meletakkan kebenaran keilahiahan sebagai nilai dasar, maka ini bersesuaian dengan fitrah manusia. Sementara kebenaran hukum modern meletakkan kebenaran nilai diatas dasar sifat alamiah manusia, rasio-empiris mutlak sebagai sumber kebenaran, serta manusia sebagai pusat kehidupan. Pandangan ini akan menimbulkan lingkaran setan karena manusia akan berputar-putar dalam labirin relativisitasnya sendiri. Hal ini disebabkan karena memberikan sifat mutlak pada kebenaran rasio, sementara satu sisi tidak berdaya mengingkari keberadaan realitas kebenaran sejati yang melingkupi alam semesta. Hukum dalam wujud konstitusi negara juga terus-menerus berubah menurut kehendak rasio, mengikuti irama perubahan masyarakat. Konstitusi atau sistem hukum dalam dirinya sendiri mengandung kelemahan dasar yakni, karena materi muatannya mengikuti kehendak rasio, berdasar realitas empiris, sehingga kebenarannya adalah gejala manusiawi, kemudian dipaksakan secara normatif sebagai kitab suci yang di mutlakkan, sementara kandungan kebenarannya bersifat relatif.

Konstitusionalisme, dalam dinamika dan latar belakang problem dasar peradaban modern manusia perlu mempertimbangkan ulang relasi kebenaran Ilahiyah doktrin-doktrin moral religi/spiritual (sebagai basis kebenaran) dan kebenaran rasio manusia (sebagai penafsir doktrin) dalam menghadapi realitas kehidupan masyarakat. Keterpaduan ini urgen dalam konstruksi suatu konstitusi negara. Kebenaran suci doktrin ketuhanan yang 
hidup dalam masyarakat dapat bersenyawa dengan kebenaran rasional dalam merespon realitas kehidupan, sehingga konstitusi negara merefleksikan kebenaran keilahiahan dan kemanusiaan sekaligus. Inilah karakteristik konstitusi masa depan. Secara sederhana dapat digambarkan, sebagai berikut:

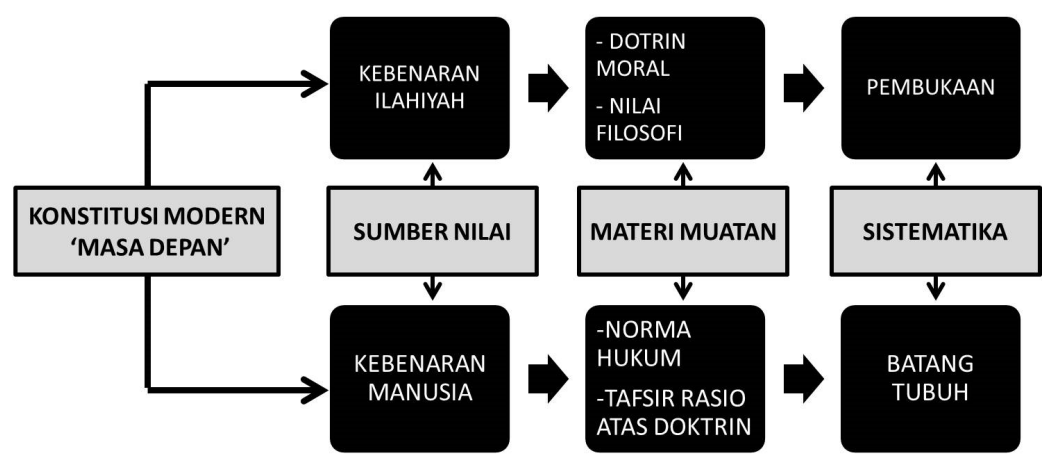

Bagan 3. Karakteristik konstitusi masa depan

Persenyawaan kebenaran keilahiahan (doktrin moral) dan kebenaran manusiawi (rasionalitas hukum) dalam konstitusi modern, diasumsikan menjadi jalan keluar beragam krisis fundamental kehidupan manusia dalam peradaban modern. Hal ini sekaligus bermakna terbukanya peluang simbiosis pandangan dunia tradisi yang berorientasi religi dengan pandangan dunia modern yang berorientasi ilmiah. Keterpaduan ini dapat menjadi kekuatan baru dalam sistem kehidupan masyarakat menghadapi berbagai permasalahan fundamental peradaban, sekarang maupun masa yang akan datang.

\section{SIMPULAN}

Sejarah modern mempertontonkan dikotomi moral dan hukum demikian tajam. Hal ini terjadi karena dua arus pemikiran berbeda, dalam warisan historisnya masing-masing. Perbedaan ini berkenaan dengan dua model epistemologi pengetahuan manusia, yakni: (1) epistemologi pengetahuan klasik yang berorientasi pada kebenaran Ilahi dengan berdasar pada doktrin kebenaran mutlak dan rasionalisme manusia serta bersesuaian dengan kebenaran imani. (2) Epistemologi pengetahuan modern yang berorientasi pada kebenaran 
manusiawi dengan rasionalisme obyektif sebagai satu-satunya sumber kebenaran. Hal yang disebut pertama mendasarkan diri pada ontologi metafisik, sementara yang kedua, mengacu pada ontologi materialisme.

Dua hal tersebut di atas menjadi sumber utama saling silang kebenaran moral dan hukum di abad modern. Hegemoni materialisme dan positivisme telah memarginalkan spiritualisme dan rasio-imani dalam sepanjang sejarah modern. Kondisi ini membawa implikasi pada munculnya berbagai polemik dalam konstitusi modern. Salah satu diantaranya adalah munculnya fenomena masyarakat baru yang berlabel LGBT. Bagi masyarakat sekuler, memberikan kepada mereka hak-hak konstitusional tidak menjadi soal. Namun, berbeda halnya dengan masyarakat yang berpandangan hidup spiritual atau religi, tentu hal ini akan menjadi masalah. Oleh karena itu perlu upaya untuk mendamaikan dikotomi hukum dan moral sebagaimana contoh kasus di atas melalui proses revitalisasi konstitusi. Hal tersebut dilakukan dengan membuat orientasi baru terhadap konstitusi melalui diktum 'memuliakan moral dengan mengutamakan hukum dalam satu sistem hidup modern'.

Konstitusi modern masa depan adalah perpaduan kebenaran moral religi/spiritual dan kebenaran hukum rasional-imani dalam satu bangunan konstitusi negara. Dengan demikian, fitrah manusia yang berkecenderungan mengakui kebenaran mutlak doktrin ilahiah menjadi tersalurkan secara nyata berbarengan dengan dimensi rasionalitas. Rasio pada konteks ini akhirnya berfungsi sebagai penyelaras kebenaran moral dengan dinamika realitas kehidupan empiris.

\section{DAFTAR PUSTAKA}

Adian, D. G. (2002). Menyoal Objektivisme Ilmu Pengetahuan; Dari David Hume sampai Thomas Khun. Jakarta: Teraju.

Ali, A. (2009). Menguak Teori Hukum - Legal Theory-dan Teori Peradilan - Judicial Prudence. Jakarta: Kencana.

Atmadja, I. D. G, S., \& Wiyono, S. (2014). Filsafat Ilmu; dari Pohon 
pengetahuan Sampai Karakter Keilmuan Ilmu Hukum. Malang: Madani.

Bertens, K. (2007). Etika. Jakarta: Gramedia.

Capra, F. (2000). Titik Balik Peradaban; Sains, Masyarakat dan Kebangkitan Kebudayaan. Yogyakarta: Bentang Budaya.

Djokosutono. (1982). Hukum Tata Negara. Jakarta: Ghalia Indonesia.

Friedrich, C. J. (2010). Filsafat Hukum Perspektif Historis. Bandung: Nusa Media.

Hardiman, F. B. (2016). Melampaui Positivisme dan Modernisme; Diskursus Filosofis tentang Metode Ilmiah dan Problem Modernitas. Yogyakarta: Kanisius.

Hart, H. L. A. (2013). Konsep Hukum. Bandung: Nusa Media.

Hourani, G. F. (1980). Ethical Presupposition of the Qur'an. Journal Muslim World, LXX(1), 1-28.

Kattsoff, L. O. (1996). Pengantar Filsafat. Yogyakarta: Tiara Wacana.

Kelsen, H. (2015). Teori Umum tentang Hukum dan Negara. Bandung: Nusa Media.

Kurnia, T. S. (2014). Konstitusi HAM: UUD NRI Tahun 1945 dan Mahkamah Konstitusi RI. Yogyakarta: Pustaka Pelajar.

Kusuma, E. H. (2015). "Hubungan Antara Moral Dan Agama Dengan Hukum". Jurnal Pendidikan Pancasila dan Kewarganegaraan, 28(2), 52-58.

Patterson, D. (1999). A Companion to Philosophy of Law and Legal Theory. UK: Blackwell Publisher Ltd.

Tim Penulis Cipta Adi Pusaka. (1990). Ensiklopedi Nasional Indonesia Jilid 10. Jakarta: Cipta Adi Pusaka.

Quasem, M. A. (1988). Etika al-Ghazali: Etika Majemuk dalam Islam. Bandung: Pustaka.

Schuon, F. (1998). Islam dan Filsafat Perenial. Bandung: Mizan.

Strong, C. F. (2010). Konstitusi-konstitusi Politik Modern. Bandung: 
Nusa Media.

Sudarsono. (1991). Pengantar Ilmu Hukum. Jakarta: Rineka Cipta.

Susanto, A. F. (2010). Dekonstruksi Hukum; Eksplorasi Teks dan Model Pembacaan. Yogyakarta: Genta Publishing.

Suseno, F. M. (1997). 13 Tokoh Etika. Yogyakarta: Kanisius.

Suseno, F. M. (2006). Etika Dasar; Masalah-Masalah Pokok Filsafat Moral. Yogyakarta: Kanisius.

Tafsir, A. (2004). Filsafat Umum; Akal dan Hati Sejak Thales Sampai Capra. Bandung: Remaja Rosda Karya.

Tafsir, A. (2011). Filsafat Umum; Sebuah Pengantar. Bandung: Remaja Rosda Karya.

Ward, I. (2014). Pengantar Teori Hukum Kritis. Bandung: Nusa Media. 